\title{
Multiple response optimization of blueberry juice depectinization
}

\author{
Juan Manuel Castagnini ${ }^{1 *}$ Luz Marina Zapata ${ }^{1}$ Carlos Fabio Quinteros $^{1}$ Alicia Noceti ${ }^{1}$
}

${ }^{1}$ Facultad de Ciencias de la Alimentación, Universidad Nacional de Entre Ríos, Av. Monseñor Tavella, 1450, CP 3200, Concordia, Entre Ríos, Argentina. E-mail: jmcastagnini@gmail.com. "Corresponding author.

\begin{abstract}
To obtain blueberry juice with a high content of antioxidants it is necessary to introduce an enzymatic depectinization step into the process. Due to the importance of this step in the final properties of blueberry juice it is critical that the operation conditions be optimized. The aim of this research was to evaluate the effects of temperature, duration of treatment and enzymatic complex concentration on anthocyanin content and juice yield during enzymatic depectinization. Results indicated that the best factor combination was $50^{\circ} \mathrm{C}$ during $1.3 \mathrm{~h}$ and $4 \mathrm{mg} 100 \mathrm{~g}^{-1}$ of LAFASE ${ }^{\circledR}$ CLARIFICATION and $8 \mathrm{mg} 100 \mathrm{~g}^{-1}$ of LAFASE ${ }^{\circledR}$ HE GRAND CRU enzymatic complex concentration. Under these conditions, blueberry juice with $798.41 \pm 8.03 \mathrm{mg}$ of cyanidin-3-glucoside $L^{-1}$ and a juice yield of $87 \%$ was obtained. The combination of the response surface and desirability function methodologies enabled the optimization of the blueberry juice during the depectinization step, in terms of anthocyanin content and juice yield.

Key words: blueberry juice, enzymatic depectinization, multiple response optimization.
\end{abstract}

Otimização de múltiplas respostas durante a despectinização do suco de mirtilo

RESUMO: Para obter o suco de mirtilo com um alto teor de antioxidantes, é necessário realizar uma etapa de despectinização enzimática durante o processo. Esta etapa influenciará nas propriedades finais do suco de mirtilo, então, é necessário que as condições de operação sejam otimizadas. O objetivo deste trabalho foi avaliar os efeitos da temperatura, duração do tratamento e concentração do complexo enzimático na concentração de antocianinas e no rendimento do suco durante a despectinização enzimática. Os resultados indicaram que a melhor combinação de parâmetros foi de $50^{\circ} \mathrm{C}$, durante 1 à 3 h e uma concentração de complexo enzimático de $4 m g$ 100g de LAFASE $^{\circledR}$ CLARIFICATION e $8 \mathrm{mg} 100 \mathrm{~g}^{-1}$ de LAFASE ${ }^{\circledR}$ HE GRAND CRU. Sob estas condições, foi obtido o suco de mirtilo com 798.41 $\pm 8.03 m g$ decianidina-3-glicosideo $L^{-1}$ e um rendimento de suco de 87\%. A combinação das metodologias de superficie de resposta em função da preferência possibilitaram a otimização da despectinização do suco de mirtilo, em termos de teor de antocianinas e rendimento de suco.

Palavras-chave: suco de mirtilo, despectinização enzimática, otimização de múltiplas respostas.

\section{INTRODUCTION}

Blueberries (Vaccinium corymbosum) are a different phytonutrients rich dietary source. Among the many phenolic compounds, anthocyanins have a great amount of attention since they possess potent antioxidant activity (PRIOR et al., 1998; SEERAM, 2008; VRHOVSEK et al., 2012). Anthocyanins have shown an important role in the prevention of macular degeneration (TREVITHICK \& MITTON, 1999), neuronal diseases, cardiovascular diseases, cancer, diabetes (CHAMBERS \& CAMIRE, 2003; KRAFT et al., 2005; MARTINEAU et al., 2006; NETO, 2007; SHUKITT-HALE et al., 2008; PATRAS et al., 2010) and urinary tract disorders (KALT \& DUFOUR, 1997;
HOWELL et al., 2005; JEPSON \& CRAIG, 2007). Because of their beneficial role as micronutrients, it is of utmost importance to measure the changes in polyphenolics during processing to better assess the dietary value of the processed products (RAWSON et al., 2011; HOWARD et al., 2012).

During blueberry juice processing, one of the main problems is gelification due to high pectin concentration. Rapid gelation process prevents the application of subsequent unit operations as filtration, pasteurization, concentration, and others. Fruit juice depectinization through the use of pectinases has been presented as an efficient alternative to reduce turbidity and enhance juice yield (SANDRI et al., 2011, 2013). However, a significant loss of 
anthocyanin content was observed during juice processing (SRIVASTAVA et al., 2007). In addition, information on how different processing steps affect the content of bioactive compounds in the final product is limited (BROWNMILLER et al., 2008; SABLANI et al., 2010).

A useful tool for process optimization that enables determination of the optimal conditions for multiple influential factors with a limited number of experiments is response surface methodology (SHI \& YU, 2005; VARRONE et al., 2012). This methodology has been successfully used to optimize clarification of carambola fruit (LIEW ABDULLAH et al., 2007), pectin extraction from lemon byproducts (MASMOUDI et al., 2008) and enzymatic clarification of banana juice (LEE et al., 2006) among other applications. However, it has not been utilized to optimize the blueberry juice depectinization process.

The aim of this work was to evaluate the effects of temperature, duration of treatment and enzymatic complex concentration on anthocyanins content and juice yield during enzymatic depectinization.

\section{MATERIAL AND METHODS}

\section{Sample preparation}

Snow chaser blueberries were harvested and placed in polyethylene terephthalate trays and immediately introduced into a cooling chamber at $0 \pm 0.5^{\circ} \mathrm{C}$ until use. Blueberries were washed, weighed and then crushed with a food processor (MR 400 Plus, Braun, Spain). An enzymatic depectinization with two commercial enzymatic packs, LAFASE ${ }^{\circledR}$ CLARIFICATION (E1) and LAFASE ${ }^{\circledR}$ HE GRAND CRU (E2) (Laffort, France) was carried out. Finally, the juice was filtered through a $0.5 \mathrm{~mm}$ sieve and then centrifuged (ALRESA Digicen, Álvarez Redondo S.A., Spain) at $2706 \mathrm{x}$ g for 20 minutes. The solid residues were discarded and the supernatant is referred to as blueberry juice.

\section{Anthocyanins}

The $\mathrm{pH}$ differential spectrophotometric method developed by GIUSTI \& WROLSTAD (2001) was used to assess the total monomeric anthocyanin (TA) content. Aqueous buffers with $\mathrm{pH} 1.0(\mathrm{KCl}$ $0.025 \mathrm{M})$ and $4.5\left(\mathrm{CH}_{3} \mathrm{COONa} 0.4 \mathrm{M}\right)$ were utilized to dilute the samples. Absorbance measurements were taken at 510 and $700 \mathrm{~nm}$ against a blank cell filled with distilled water. A $2690 \mathrm{~m}^{2} \mathrm{~mol}^{-1}$ molar extinction coefficient was used for the Cyanidin-3-O-glucoside. Results were expressed as milligrams of Cyanidin-3$\mathrm{O}$-glucoside equivalent per liter of juice.
Juice yield (JY)

Mass relationship between weight of juice and initial blueberry weight was calculated. Juice yield was expressed as grams of juice per $100 \mathrm{~g}$ blueberries.

\section{Experimental design}

An experimental design with STATGRAPHICS Centurion XV package was carried out. Four factors were studied in the following experimental range: temperature $(\mathrm{T}): 0-100^{\circ} \mathrm{C}$; time (t): 0-2.5h; concentration of enzymatic pack LAFASE ${ }^{\circledR}$ HE GRAND CRU (E1): 0-8mg 100 ${ }^{1}$ blueberries and LAFASE $^{\circledR}$ CLARIFICATION (E2): 0-16mg 100 $\mathrm{g}^{-1}$ blueberries. Total monomeric anthocyanin content and juice yield were selected as response variables. Using a Draper-Lin small composite design, a total of 34 experiences were carried out, each by triplicate. Results were analyzed by response surface methodology. In order to maximize anthocyanin content and juice yield, the level of each factor was optimized by the desirability function approach.

\section{RESULTS AND DISCUSSION}

\section{Effects of experimental factors on total anthocyanins concentration}

Results showed a wide variation of total anthocyanin concentration and juice yield as a function of the experimental conditions (Table 1), which indicated the relevance of this optimization study. The highest concentration of total anthocyanins occurred when the experiment was carried out at $50^{\circ} \mathrm{C}$ during $1.3 \mathrm{~h}$ and 4 and $8 \mathrm{mg} 100 \mathrm{~g}^{-1}$ of blueberry E1 and E2 enzyme concentration respectively (Table 1). The experimental data were analyzed using multiple regression, resulting in Equation 1 where only the significant factors were included.

$A T=21933+1662 . T-80719 . t-2721 . E 1-1384 . E 2-$ 0.021. $T^{2}+0.10 . T . t-207.55 . T . E 1-103.78 . T . E 2-26.95 . t^{2}+$ 10097.t.E1+5049.t.E2

Statistical analysis revealed that this experimental design described the relationship between total anthocyanins and the experimental factors $(\mathrm{P}<0.05)$ adequately. The high value of $\mathrm{R}^{2}(0.975)$ indicated that only $2.5 \%$ of the total variation was not explained. Temperature $(\mathrm{T})$, time $(\mathrm{t})$, enzyme concentration (E1 and E2), $\mathrm{T}^{2}$ and $\mathrm{t}^{2}$, as well as T-t, T-E1, T-E2, t-E1, t-E2 interactions were significant $(\mathrm{P}<0.05)$.

In order to visualize the effects of the factors on total anthocyanins response, contour 
Table 1 - Blueberry juice depectinization experimental design.

\begin{tabular}{|c|c|c|c|c|c|}
\hline Temperature & Time & E1 & E2 & Total anthocyanins & Juice Yield \\
\hline$\left({ }^{\circ} \mathrm{C}\right)$ & (h) & $\left(\mathrm{mg} 100 \mathrm{~g}^{-1}\right)$ & $\left(\mathrm{mg} 100 \mathrm{~g}^{-1}\right)$ & (mg Cyd-3-O-glu L ${ }^{-1}$ ) & $\left(\mathrm{g} 100 \mathrm{~g}^{-1}\right)$ \\
\hline 0 & 1.3 & 4 & 8 & $89.5 \pm 0.3^{a}$ & $76.0 \pm 2.6^{\text {cde }}$ \\
\hline 20 & 0.5 & 0 & 16 & $360.8 \pm 33.0^{d}$ & $79.1 \pm 1.2^{\text {def }}$ \\
\hline 20 & 0.5 & 8 & 0 & $330.6 \pm 5.5^{d}$ & $46.5 \pm 1.5^{a}$ \\
\hline 20 & 2 & 0 & 16 & $336.0 \pm 24.0^{d}$ & $81.9 \pm 1.4^{e f}$ \\
\hline 20 & 2 & 8 & 0 & $264.5 \pm 17.4^{c}$ & $80.1 \pm 0.3^{\text {def }}$ \\
\hline 50 & 0 & 4 & 8 & $210.5 \pm 2.3^{b}$ & $70.7 \pm 0.0^{c}$ \\
\hline 50 & 1.3 & 0 & 0 & $319.5 \pm 26.0^{d}$ & $69.4 \pm 2.2^{c}$ \\
\hline 50 & 1.3 & 4 & 8 & $659.2 \pm 21.4^{e}$ & $74.6 \pm 4.0^{c d}$ \\
\hline 50 & 1.3 & 8 & 4.8 & $358.2 \pm 37.7^{d}$ & $85.3 \pm 2.3^{f}$ \\
\hline 50 & 2.5 & 4 & 8 & $254.1 \pm 25.1^{b c}$ & $75.1 \pm 1.1^{\text {cde }}$ \\
\hline 80 & 0.5 & 8 & 0 & $337.3 \pm 2.4^{d}$ & $56.3 \pm 0.3^{b}$ \\
\hline 80 & 0.5 & 0 & 16 & $328.3 \pm 23.8^{d}$ & $61.1 \pm 1.1^{b}$ \\
\hline 80 & 2 & 0 & 16 & $357.5 \pm 23.9^{d}$ & $47.5 \pm 2.4^{a}$ \\
\hline 80 & 2 & 8 & 0 & $354.2 \pm 25.4^{d}$ & $47.2 \pm 4.6^{a}$ \\
\hline 100 & 1.3 & 4 & 8 & $244.4 \pm 16.6^{b c}$ & $70.1 \pm 1.9^{c}$ \\
\hline
\end{tabular}

plots were generated by varying two factors and holding the other two constant (Figure 1). Figure 1a allowed the identification of the anthocyanin maximum concentration area in this experimental design. Temperature and treatment time were increased to $60^{\circ} \mathrm{C}$ and $1.4 \mathrm{~h}$, respectively, resulting in a higher concentration of total anthocyanins. However, when these factors values were higher than the aforementioned ones, a decrease in total anthocyanins was observed. These results could be explained if a combination of phenomena is considered. Firstly, an increase of anthocyanin solubility and diffusivity coefficient resulted from temperature increase, as suggested by CACACE \& MAZZA (2003) and BRAMBILLA et al. (2011). Secondly, a temperature dependent degradation process that becomes significant above $60^{\circ} \mathrm{C}$ is probably due to the loss of the glycoside molecule from position three of the anthocyanin structure and the polyphenolic ring opening (FENNEMA, 2000). Regarding treatment duration, a longer treatment caused an increase in total anthocyanin concentration until the extraction and degradation rates were even as observed by other authors (IBARZ RIBAS et al., 2000; ROMERO CASCALES, 2008). As for commercial enzyme concentration and temperature, an increase in any factor caused an increase of total anthocyanin content (Figure 1b) until $4 \mathrm{mg} 100 \mathrm{~g}^{-1} \mathrm{E} 1$ concentration and $48^{\circ} \mathrm{C}$ were reached, while higher E1 concentration and temperature resulted in a total anthocyanin decrease. A similar behavior was observed in

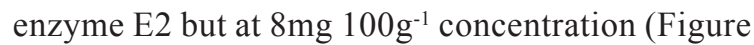
1c). Finally, it was observed that the highest anthocyanin content was found within $76-79 \mathrm{~min}$ treatment range and with $3.6-4.4 \mathrm{mg} 100 \mathrm{~g}^{-1} \mathrm{E} 1$ and $7-8 \mathrm{mg}^{100 \mathrm{~g}^{-1}} \mathrm{E} 2$ concentrations respectively (Figure 1d and Figure 1e). With regards to the added enzyme concentration, ROMERO CASCALES (2008) noted that while some studies showed a color increase in the vinification process where pectolytic exogenous enzymes were applied, others have reported no benefits. This may be due to a large heterogeneity among different commercial preparations. These authors also reported that other studies had obtained wines with more color as they worked with minimal enzyme doses $(0.3 \%)$ and wines with less color when they worked with high enzyme doses $(0.7 \%)$. They suggested that this effect could be caused by enzyme preparations containing $\beta$-glucosidase activity, that apparently had a bleaching effect on pigments extracted from various fruits.

\section{Effect of the experimental factors on juice yield}

There is a wide variety of results ranging from 46 to $85 \%$. The lowest juice yield value was obtained with treatments shorter than $30 \mathrm{~min}$ or longer than $120 \mathrm{~min}$ and at temperatures higher than $80^{\circ} \mathrm{C}$ (Table 1). The highest juice yield value was obtained by using the following factor combination: $50^{\circ} \mathrm{C}$, 
(a) $\mathrm{E} 1=4 \mathrm{mg} / 100 \mathrm{~g}, \mathrm{E} 2=8 \mathrm{mg} / 100 \mathrm{~g}$

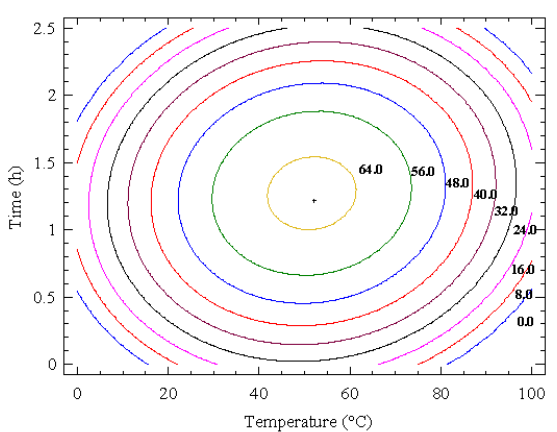

(c) Time $=1.3 \mathrm{~h} ; \mathrm{E} 1=4 \mathrm{mg} / 100 \mathrm{~g}$

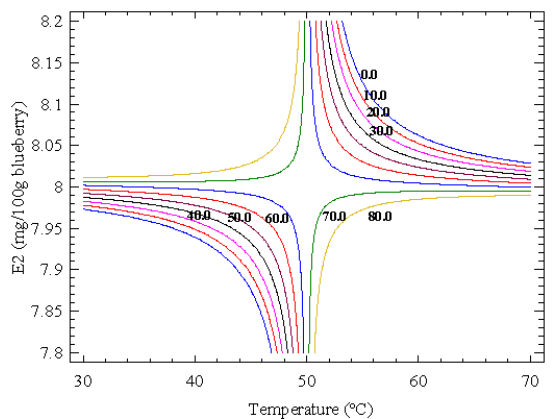

(b) Time $=1.3 \mathrm{~h} ; \mathrm{E} 2=8 \mathrm{mg} / 100 \mathrm{~g}$

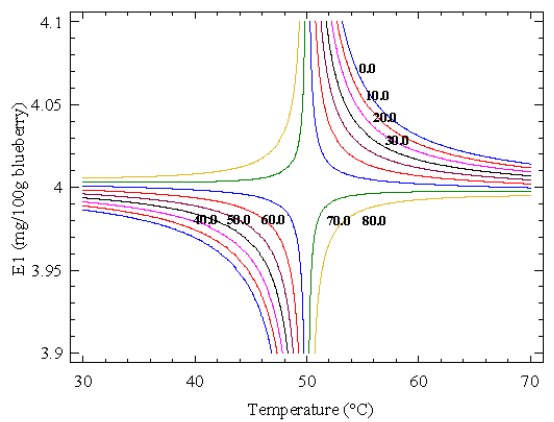

(d) Temperature $=50^{\circ} \mathrm{C}, \mathrm{E} 2=8 \mathrm{mg} / 100 \mathrm{~g}$

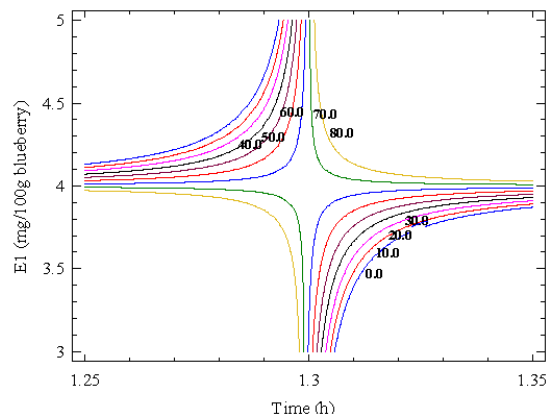

ime (h)

(e) Temperature $=50^{\circ} \mathrm{C}, \mathrm{E} 1=4 \mathrm{mg} / 100 \mathrm{~g}$

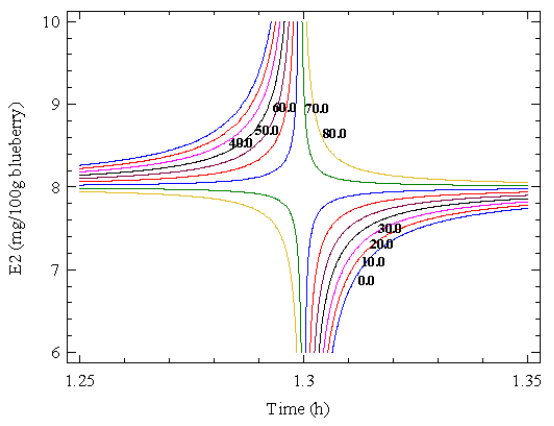

Figure 1 - Contour plots for total anthocyanins (mg cyanidin-3-O-glucoside $\mathrm{L}^{-1}$ juice). a) Contour plot for anthocyanin content as a function of process time and temperature when enzymes E1 and E2 concentration was 4 and $8 \mathrm{mg}^{100 \mathrm{~g}^{-1}}$. b), c), d) and e) Contour plot for anthocyanin content as a function of two factors maintaining the other two constant (where the highest variations were observed).

1.3-1.5h treatment and 4 and $8 \mathrm{mg} 100 \mathrm{~g}^{-1}$ enzyme concentration for E1 and E2 respectively.

Multiple regression analysis was carried out resulting in a second order polynomial equation (Equation 2). Only the significant terms were included in the equation.

$J Y=36350+2378 . T-119371 . t-4488 . E 1-2363$. E2-0.002.T2-0.28.T.t-297.T.E1-145.T.E214925.t.E1+7461.t.E2-8.95.E1.E2
The high $\mathrm{R}^{2}=0.885$ indicates that the fitting quality was satisfactory. The terms T, t, E1, E2, T2, T t, T E1, T E2, t E1, t E2 and E1 E2 were significant $(\mathrm{P}<0.05)$.

The contour plots generated for juice yield showed that increasing temperature to $70^{\circ} \mathrm{C}$ and treatment duration to $1,3 \mathrm{~h}$ caused an increase in juice yield. A juice yield decrease was observed above these conditions (Figure 2a).

Temperatures within the $49-51^{\circ} \mathrm{C}$ range and E1 enzyme concentration within 3.6 to $4.4 \mathrm{mg} 100 \mathrm{~g}^{-1}$ 
led to an increase in juice yield; while a decrease of the response variable was observed above the aforementioned values (Figure 2b). A similar behavior was observed for E2 between 7 and $9 \mathrm{mg}$ $100 \mathrm{~g}^{-1}$ blueberries (Figure 2c). In the case of E1 and $\mathrm{E} 2$ as a function of treatment time, the contour plots showed similar results to those mentioned above (Figure 2d and Figure 2e). Neither a short time treatment (less than $0.5 \mathrm{~h}$ ) nor a long treatment (above $2 \mathrm{~h}$ ) rendered a high yield value.

\section{Optimization of enzymatic depectinization}

By applying the desirability function method, the optimum conditions for obtaining blueberry juice were determined (Figure 3). The desirability function value obtained was 0.9583 . (a) $\mathrm{E} 1=4 \mathrm{mg} / 100 \mathrm{~g}, \mathrm{E} 2=8 \mathrm{mg} / 100 \mathrm{~g}$

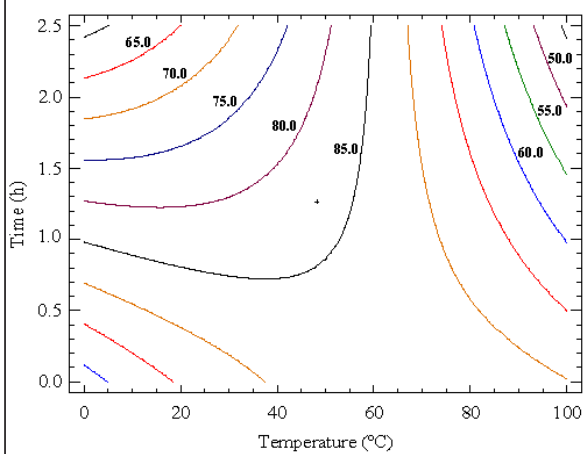

(c) Time $=1.3 \mathrm{~h} ; \mathrm{E} 1=4 \mathrm{mg} / 100 \mathrm{~g}$

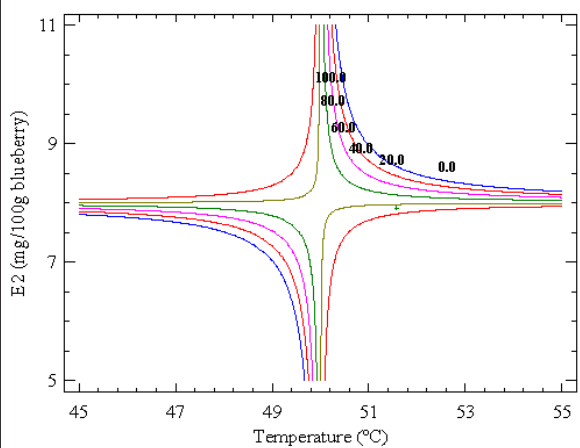

(b) Time $=1.3 \mathrm{~h} ; \mathrm{E} 2=8 \mathrm{mg} / 100 \mathrm{~g}$

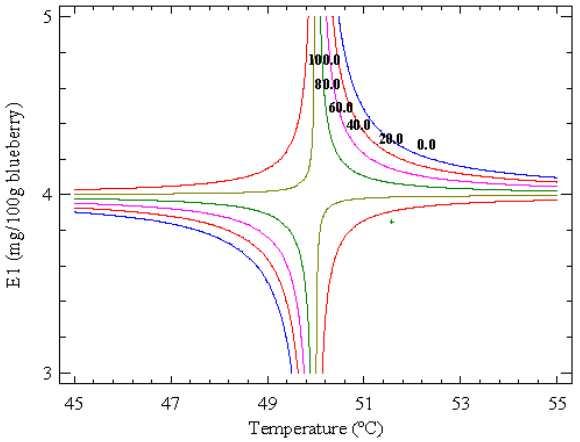

(d) Temperature $=50^{\circ} \mathrm{C}, \mathrm{E} 2=8 \mathrm{mg} / 100 \mathrm{~g}$

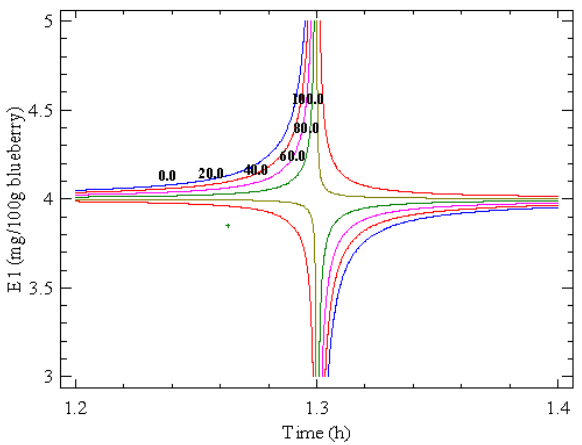

(e) Temperature $=50^{\circ} \mathrm{C}, \mathrm{E} 1=4 \mathrm{mg} / 100 \mathrm{~g}$

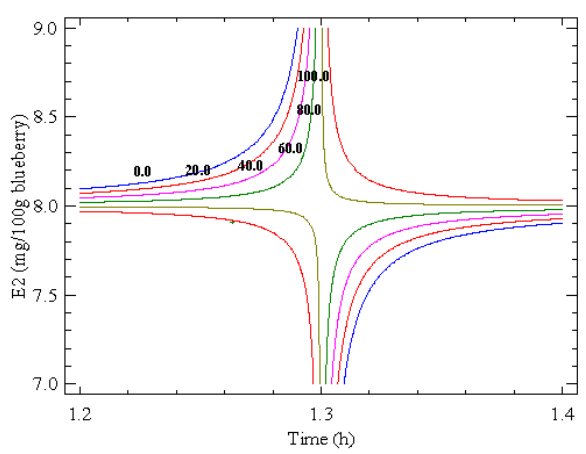

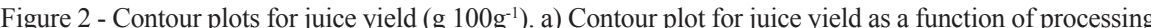
time and temperature when enzymes E1 and E2 concentration was 4 and $8 \mathrm{mg}^{100 \mathrm{~g}^{-1}} \cdot \mathrm{b}$ ), c), d) and e) Contour plot for juice yield as a function of two factors maintaining the other two constant (where the highest variations were observed). 


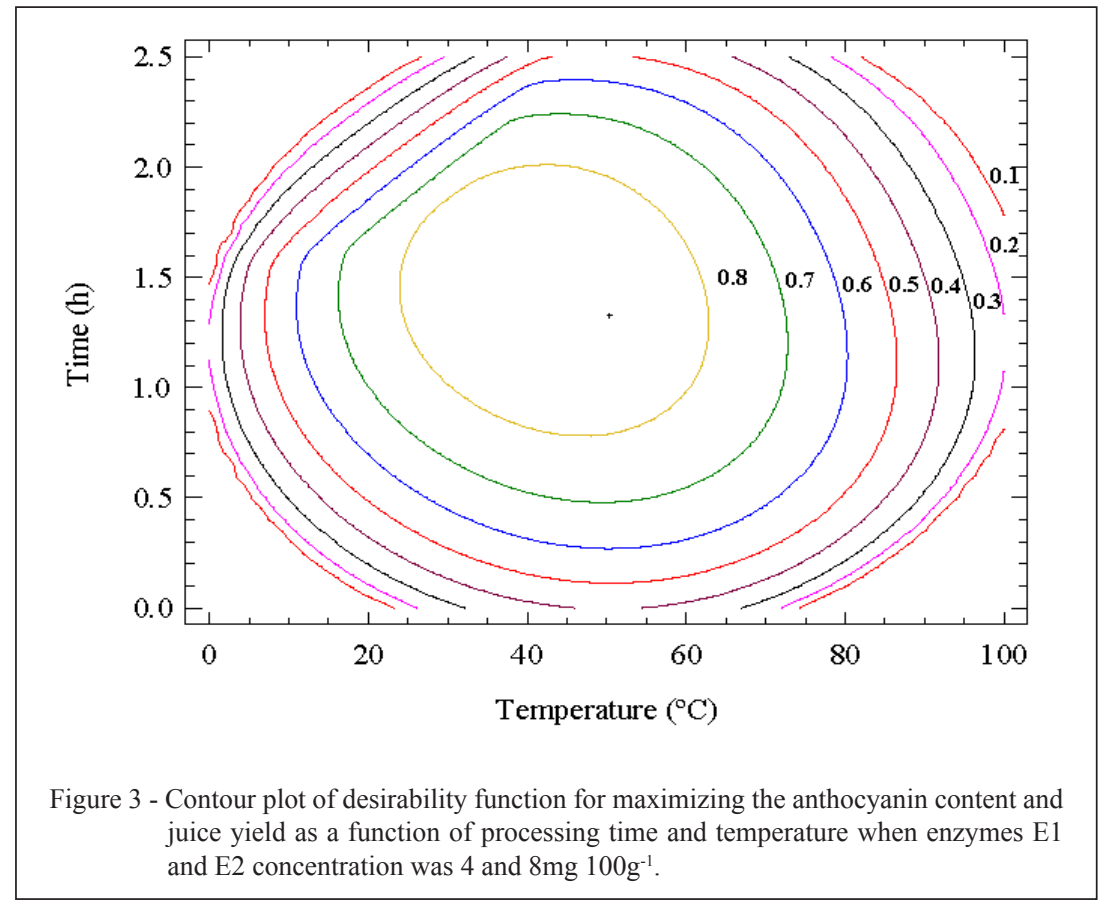

Optimum conditions that provided the highest values of total anthocyanins (712mg of cyanidin-3-glucoside $1 \mathrm{~L}^{-1}$ of juice) and juice yield ( $\left.85 \%\right)$ were: temperature $=50^{\circ} \mathrm{C} ;$ duration $=1.3 \mathrm{~h} ;$ E1 concentration $=4 \mathrm{mg}$ $100 \mathrm{~g}^{-1} ;$ E2 concentration $=8 \mathrm{mg} 100 \mathrm{~g}^{-1}$.

Optimized conditions obtained through the application of the desirability function were utilized to obtain blueberry juice. In addition, an adjustment to the process was introduced: the vessels head space was reduced to a minimum in order to avoid the contact with oxygen during the depectinization stage.

The blueberry juice obtained had a $798.41 \pm 8.03 \mathrm{mg}$ cyanidin-3-glucoside $1 \mathrm{~L}^{-1}$ concentration and the juice yield was $87 \%$. This anthocyanin concentration was slightly higher than the value predicted by the desirability function and $20 \%$ higher than the values obtained during the experimental design. This better result could be related to the smaller head space left in the vessels during the last experiment. Oxygen is well known as a destabilizing agent in processed products containing anthocyanins (FRANCIS, 1989), and it also has a negative effect on the antioxidant capacity of blueberry juice (KALT et al., 2000).

\section{CONCLUSION}

Response surface methodology and desirability function enabled the evaluation of a wide range of temperature, duration of treatment and enzyme concentration. The best combination of process conditions to obtain total anthocyanin and juice yield highest values were: temperature $=$ $50^{\circ} \mathrm{C}$; duration $=1.3 \mathrm{~h} ;$ E1 concentration $=4 \mathrm{mg} / 100 \mathrm{~g}$; E2 concentration $=8 \mathrm{mg} / 100 \mathrm{~g}$ within the studied experimental range.

\section{ACKNOWLEDGEMENTS}

The authors wish to thank N. Krunfli for her technical assistance. This research was supported by the Universidad Nacional de Entre Ríos through the research project titled "PIDUNER 8068: Diseño de jugo de arándanos con propiedades antioxidantes y probióticas".

\section{REFERENCES}

BRAMBILLA, A. et al. Study of the influence of berry-blanching on syneresis in blueberry purées. Procedia Food Science, v.1, p.1502-1508, 2012. Available from: <http://www.sciencedirect. com/science/article/pii/S2211601X11002239>. Accessed: Dec. 5, 2016. doi: 10.1016/j.profoo.2011.09.222.

BROWNMILLER, C. et al. Processing and storage effects on monomeric anthocyanins, percent polymeric color, and antioxidant capacity of processed blueberry products. Journal of Food Science, v.73, n.5, p.H72-H79, 2008. Available from: <http://onlinelibrary. wiley.com/doi/10.1111/j.1750-3841.2008.00761.x/abstract;jsessioni d=ABA290DFA6103B04FBD4730E6704B473.f01t04>. Accessed: Dec. 5, 2016. doi: 10.1111/j.1750-3841.2008.00761.x.

CACACE, J.; MAZZA, G. Optimization of extraction of anthocyanins from black currants with aqueous ethanol. Journal 
of Food Science, v.68, n.1, p.240-248, 2003. Available from: $<$ http://onlinelibrary.wiley.com/doi/10.1111/j.1365-2621.2003. tb14146.x/abstract>. Accessed: Dec. 5, 2016. doi: 10.1111/j.13652621.2003.tb14146.x.

CHAMBERS, B.; CAMIRE, M. Can cranberry supplementation benefit adults with type 2 diabetes? Diabetes Care, v.26, p.26952696, 2003. Available from: <http://care.diabetesjournals.org/ content/26/9/2695.2.long >. Accessed: Dec. 5, 2016. doi: 10.2337/ diacare.26.9.2695-a.

FENNEMA, O.R. Food chemistry. Zaragoza: Acribia, 2000. $1258 \mathrm{p}$.

FRANCIS, F.J. Food colorants: anthocyanins. Critical Reviews in Food Science and Nutrition, v.28, n.4, p.273314, 1989. Available from: <http://www.tandfonline.com/doi/ abs/10.1080/10408398909527503>. Accessed: Dec. 5, 2016. doi: $10.1080 / 10408398909527503$

GIUSTI, M.M.; WROLSTAD, R.E. Characterization and measurement of anthocyanins by UV-visible spectroscopy. Current Protocols in Food Analytical Chemistry. F1.2.1-F1.2.13, 2001. Available from: <http://onlinelibrary.wiley. com/doi/10.1002/0471142913.faf0102s00/abstract>. Accessed: Dec. 5, 2016. doi: 10.1002/0471142913.faf0102s00

HOWARD, L.R. et al. Processing and storage effect on berry polyphenols: challenges and implications for bioactive properties. Journal of Agricultural and Food Chemistry, v.60, n.27, p.6678 6693, 2012. Available from: <http://pubs.acs.org/doi/abs/10.1021/ jf2046575>. Accessed: Dec. 5, 2016. doi: 10.1021/jf2046575.

HOWELL, A.B. et al. A-type cranberry proanthocyanidins and uropathogenic bacterial anti-adhesion activity. Phytochemistry, v.66, n.18, p.2281-2291, 2005. Available from: <http://www. sciencedirect.com/science/article/pii/S0031942205002499>. Accessed: Dec. 5, 2016. doi: 10.1016/j.phytochem.2005.05.022.

IBARZ RIBAS, A. et al. Métodos experimentales en la ingeniería alimentaria. Zaragoza: Acribria, 2000. p. 292.

JEPSON, R.G.; CRAIG, J.C. A systematic review of the evidence for cranberries and blueberries in UTI prevention. Molecular Nutrition \& Food Research, v.51, n.6, p.738-745, 2007. Available from: <http://onlinelibrary.wiley.com/doi/10.1002/ mnfr.200600275/abstract>. Accessed: Dec. 5, 2016. doi: 10.1002/ mnfr.200600275.

KALT, W.; DUFOUR, D. Health functionality of blueberries. HortTechnology, v.7, n.3, p.216-221, 1997. Available from: $<$ http://horttech.ashspublications.org/content/7/3/216.full.pdf $>$. Accessed: Dec. 5, 2016.

KALT, W. et al. Antioxidant capacity of processed lowbush blueberry products. Journal of Food Science, v.65, n.3, p.390393, 2000. Available from: <http://onlinelibrary.wiley.com doi/10.1111/j.1365-2621.2000.tb16013.x/abstract>. Accessed: Dec. 5, 2016. doi: 10.1111/j.1365-2621.2000.tb16013.x.

KRAFT, T.F. et al. Chemopreventive potential of wild lowbush blueberry fruits in multiple stages of carcinogenesis. Journal of Food Science, v.70, p.159-166, 2005. Available from: $<$ http://onlinelibrary.wiley.com/doi/10.1111/j.1365-2621.2005. tb07151.x/abstract>. Accessed: Dec. 5, 2016. doi: 10.1111/ j.1365-2621.2005.tb07151.x.
LEE, W. et al. Optimizing conditions for enzymatic clarification of banana juice using response surface methodology (RSM). Journal of Food Engineering, v.73, n.1, p.55-63, 2006. Available from: <http://www.sciencedirect.com/science/article/ pii/S0260877405000397>. Accessed: Dic. 5, 2016. doi: 10.1016/j. jfoodeng.2005.01.005.

LIEW ABDULLAH, A. et al. Response surface optimization of conditions for clarification of carambola fruit juice using a commercial enzyme. Journal of Food Engineering, v.81, n.1, p.65-71, 2007. Available from: <http://www.sciencedirect.com science/article/pii/S0260877406006406>. Accessed: Dec. 5, 2016. doi: 10.1016/j.jfoodeng.2006.10.013.

MARTINEAU, L.C. et al. Anti-diabetic properties of the Canadian lowbush blueberry Vaccinium angustifolium Ait. Phytomedicine, v.13, p.612-623, 2006. Available from: <http://www.sciencedirect. com/science/article/pii/S0944711306001267>. Accessed: Dec. 5, 2016. doi: 10.1016/j.phymed.2006.08.005.

MASMOUDI, M. et al. Optimization of pectin extraction from lemon by-product with acidified date juice using response surface methodology. Carbohydrate Polymers, v.74, n.2, p.185-192, 2008. Available from: <http://www.sciencedirect.com/science/ article/pii/S0144861708000775>. Accessed: Dec. 5, 2016. doi: 10.1016/j.carbpol.2008.02.003.

NETO, C.C. Cranberry and blueberry: evidence for protective effects against cancer and vascular diseases. Molecular Nutrition \& Food Research, v.51, p.652-664, 2007. Available from: $<$ http:// onlinelibrary.wiley.com/doi/10.1002/mnfr.200600279/abstract> . Accessed: Dec. 5, 2016. doi: 10.1002/mnfr.200600279.

PATRAS, A. et al. Effect of thermal processing on anthocyanin stability in foods; mechanisms and kinetics of degradation. Trends in Food Science \& Technology, v.21, n.1, p.3-11, 2010. Available from: $<$ http://www.sciencedirect.com/science/article/pii/ S0924224409002271>. Accessed: Dec. 5, 2016. doi: 10.1016/j. tifs.2009.07.004.

PRIOR, R.L. et al. Antioxidant capacity as influenced by total phenolic and anthocyanin content, maturity, and variety of vaccinium species. Journal of Agricultural and Food Chemistry, v.46, n.7, p.2686-2693, 1998. Available from: <http:// pubs.acs.org/doi/abs/10.1021/jf980145d >. Accessed: Dec. 5, 2016. doi: $10.1021 / \mathrm{jf} 980145 \mathrm{~d}$

RAWSON, A. et al. Effect of thermal and non thermal processing technologies on the bioactive content of exotic fruits and their products: review of recent advances. Food Research International, v.44, n.7, p.1875-1887, 2011. Available from: <http://www. sciencedirect.com/science/article/pii/S0963996911001554>. Accessed: Dec. 5, 2016. doi: 10.1016/j.foodres.2011.02.053.

ROMERO CASCALES, M.I. Extracción de compuestos fenólicos de la uva al vino. Papel de los enzimas de maceración. 2008. p. 253. PhD thesis - Universidad de Murcia. Available from: $<$ http://hdl.handle.net/10803/11064>. Accessed: Dic. 5, 2016.

SABLANI, S.S. et al. Effect of thermal treatments on phytochemicals in conventionally and organically grown berries. Journal of the Science of Food and Agriculture, v.90, n.5, p.769-778, 2010. Available from: <http://onlinelibrary.wiley. com/doi/10.1002/jsfa.3882/abstract>. Accessed: Dec. 5, 2016. doi: $10.1002 /$ jsfa. 3882 . 
SANDRI, I.G. et al. Clarification of fruit juices by fungal pectinases. LWT - Food Science and Technology, v.44, n.10, p.2217-2222, 2011. Available from: <http://www.sciencedirect. com/science/article/pii/S002364381100065X>. Accessed: Dec. 5, 2016. doi: 10.1016/j.lwt.2011.02.008.

SANDRI, I.G. et al. Use of pectinases produced by a new strain of Aspergillus niger for the enzymatic treatment of apple and blueberry juice. LWT-Food Science and Technology, v.51, n.2, p.469-475, 2013. Available from: <http://www.sciencedirect.com/ science/article/pii/S0023643812004392>. Accessed: Dec. 5, 2016. doi: 10.1016/j.lwt.2012.10.015.

SEERAM, N.P. Berry fruits: compositional elements, biochemical activities, and the impact of their intake on human health, performance, and disease. Journal of Agricultural and Food Chemistry, v.56, n.3, p.627-629, 2008. Available from: <http://pubs.acs.org/doi/abs/10.1021/ jf072504n>. Accessed: Dec. 5, 2016. doi: 10.1021/jf072504n.

SEKHER PANNALA, A. et al. Flavonoid B-ring chemistry and antioxidant activity: fast reaction kinetics. Biochemical and Biophysical Research Communications, v.282, p.1161-1168, 2001. Available from: <http://www.sciencedirect.com/science/ article/pii/S0006291X01947059>. Accessed: Dec. 5, 2016. doi: 10.1006/bbrc.2001.4705.

SHI, X.-Y.; YU, H.-Q. Response surface analysis on the effect of cell concentration and light intensity on hydrogen production by Rhodopseudomonas capsulata. Process Biochemistry, v.40, n.7, p.2475-2481, 2005. Available from: <http://www.sciencedirect. com/science/article/pii/S0032959204004133>. Accessed: Dec. 5, 2016. doi: 10.1016/j.procbio.2004.09.010.
SHUKITT-HALE, B. et al. Blueberry polyphenols attenuate kainic acid-induced decrements in cognition and alter inflammatory gene expression in rat hippocampus. Nutritional Neuroscience, v.11, p.172-182, 2008. Available from: <http://www.tandfonline.com/doi/ abs/10.1179/147683008X301487>. Accessed: Dec. 5, 2016. doi: $10.1179 / 147683008 \times 301487$.

SRIVASTAVA, A. et al. Effect of storage conditions on the biological activity of phenolic compounds of blueberry extract packed in glass bottles. Journal of Agricultural and Food Chemistry, v.55, n.7 p.2705-2713, 2007. Available from: <http:// pubs.acs.org/doi/abs/10.1021/jf062914w>. Accessed: Dec. 5, 2016. doi: 10.1021/jf062914w.

TREVITHICK, J.R.; MITTON, K.P. Antioxidants and diseases of the eye. In: PAPUS, A.M. (Ed.). Antioxidant status, diet, nutrition, and health. New York: CRC, 1999. p.545-566.

VARRONE, C. et al. Statistical optimization of biohydrogen and ethanol production from crude glycerol by microbial mixed culture. International Journal of Hydrogen Energy, v.37, n.21, p.16479-16488, 2012. Available from: <http://www. sciencedirect.com/science/article/pii/S0360319912004703>. Accessed: Dec. 5, 2016. doi: 10.1016/j.ijhydene.2012.02.106.

VRHOVSEK, U. et al. Identification and quantification of flavonol glycosides in cultivated blueberry cultivars. Journal of Food Composition and Analysis, v.25, n.1, p.9-16, 2012. Available from: <http://www.sciencedirect.com/science/article/ pii/S0889157511001219>. Accessed: Dec. 5, 2016. doi: 10.1016/j. jfca.2011.04.015. 